\title{
ПОЛИТИЧЕСКИЙ КЛАСС СОВРЕМЕННОЙ РОССИИ В КОНТЕКСТЕ ИНСТРУМЕНТАЛЬНОГО ПОДХОДА
}

\begin{abstract}
Аннотация: Предметом исследования в данной статье выступает политический класс современной России. Целью работы является анализ эффективности функиионирования политического класса. В качестве методологии исследования предложен инструментальный подход. Результат исследования заключается в обосновании инструментального подхода к определению понятия «политическая элита» и осуществлён анализ функционирования современного политического класса России с позиций инструментального подхода.

Ключевые слова: политология, элита, политическая элита, политический класс, правящий класс, политические решения, качество государства, эффективность политического класса, инструментальный подход, аксиологический подход.
\end{abstract}

T ермин «элита» (от французского elite - лучший, избранный и т.п.) получил широкое распространение в обществоведческой литературе для обозначения тех социальных групп, которые добиваются наивысших результатов в своей сфере деятельности. Однако наиболее острые дискуссии вокруг понятия «элита» наблюдаются в политологической литературе.

Известный в отечественной литературе с советских времён элитолог Г. Ашин в одной из своих работ представил обзор множества определений политических элит и свёл их, как впрочем, и некоторые зарубежные авторы (С. Келлер), к двум главным подходам: иенностному и структурно-функциональному [1].

Сторонники первого подхода объясняют существование элиты «превосходством» (прежде всего интеллектуальным, моральным и т.д.) одних людей над другими и это превосходство фиксируется в различного рода ценностных определениях элит. Представители второго, наиболее распространённого в западной и российской политологии подхода, при определении элит исходят из исключительной важности функции управления для общества и, поэтому тех, кто осуществляет властно-управленческие функции, относят к политической элите. Более конкретно функциональную роль правящей элиты многие зарубежные и отечественные исследователи (напр: Р. Путнэм, Г. Ашин, О. ГаманГолутвина, О. Крыштановская) сводят в основном к выработке стратегических решений. Так, Г. Ашин подчёркивает, что «одним из самых надежных способов идентификации элиты, прежде всего политической элиты, является включение в эту категорию лиц, принимающих важнейшие, стратегические решения (одним из разработчиков этого метода является (Р.Путнэм)» [1]. О. ГаманГолутвина определяет политическую элиту как «внутренне сплоченную, социальную общность, являющуюся субъектом принятия важнейших стратегических решений и обладающую необходимым для этого ресурсным потенциалом» [3, с.10]. О. Крыштановская доказывает, что политическая элита - это часть правящего класса, которая «стоит на вершине государственной пирамиды, контролируя основные, стратегические ресурсы власти, принимая решения общегосударственного уровня» [7, c.73] (курсив в приведенных определениях мой - В.Б.) Итак, такой признак как: «принятие важнейших стратегических, общегосударственных и т.n., решений» присутствует во всех представленных определениях. В этой связи некоторые авторы называют данный подход к определению элит «десизионным» (от англ. decision - решение), то есть, основанным на анализе того, «...кем принимаются стратегические решения» [3, с. 9].

Преимущества функционального подхода к определению политических элит очевидны. Он позволяет более или менее чётко идентифицировать и изучать поведение группы людей, принимающих важнейшие решения или влияющих на принятие решений, в качестве политической элиты. В соответствии с этим подходом, исследователю необходимо определить количество должностей, связанных с принятием стратегических решений и автоматически относить людей их занимающих к элите. Например, применительно к России это: Президент, Председатель правительства и некоторые министры, Председатель Государственной Думы, Председатель Совета Федерации, возможно руководители фракций Государственной Думы и др.

При данном подходе, отвечая на вопрос, что такое политическая элита, важно договориться о количестве кресел, обладатели которых и будут составлять политическую элиту.

Опираясь на этот подход некоторые исследователи определяют количественный состав отечественной элиты указывая, например, что в современной России «...только 1000 чел. может быть отнесена к элите» [7, с.375]. Правда, в этой же работе утверждается, что в современной России «к решению важнейших вопросов допущен настолько узкий круг людей, что большая часть элиты узнаёт о принятых решениях через СМИ» [7, c. 261]. Как видим, здесь автор применяет понятие «элита» уже не только к тем допущен к «решению важнейших вопросов», но и к тем из круга занимающих властно-управленческие должности, кто «узнаёт о принятых решениях через СМИ». Так какой же у этого автора критерий определения элит, остаётся не понятно? Занимать властно-управленческую должность и при этом узнавать о принятых решениях из лишь СМИ или быть 


\section{Право и политика 4 (160) • 2013}

допущенным к решению важнейших вопросов? Ответа на этот вопрос у сторонников десизионного подхода нет.

На мой взгляд, ни перечень властно-управленческих должностей, ни список лиц, принимающих важнейшие решения, сами по себе не дают основания применять к этим группам людей понятие «политическая элита». Попробую обосновать это положение.

Как мы отметили, с точки зрения функционального (десизионного) подхода правящая группа, которая принимает стратегические решения, автоматически номинируется в качестве политической элиты. Но тем самым, этот подход оставляет в тени ключевой для идентификации политических элит вопрос - качество и эффективность принимаемых решений. Поясню свою мысль, обратившись к истокам, к классическому наследию.

Дело в том, что современные сторонники функционального подхода идут вслед за одним из классиков теории элит, Вильфредо Парето (1848 - 1923). Парето также указывал, что правящую элиту составляют те, «...кто прямо или косвенно играет заметную роль в управлении обществом» [8, с. 61]. Но следует заметить, что в определении правящей элиты Парето оказался не совсем последователен. В случае, когда итальянский автор определяет общее понятие «элита» он выдвигает критерий достижения «наивысших результатов в своей сфере деятельности». Он чётко говорит следующее: «в каждой сфере человеческой деятельности» можно выделить класс тех, кто обладает исключительными качествами, позволяющими добивается наивысших результатов в этой сфере. «...Класс тех, кто имеет наиболее высокие индексы в своей сфере деятельности ...мы назовём избранным классом или элитой» [8, с. 61]. В случае же, когда он определяет правящую элиту - выдвигается критерий «заметная роль в управлении обществом». Таким образом, критерий «достижения наивысших результатов» подменяется «заметной ролью в управлении обществом». Но ведь очевидно, что по отношению к тем, кто играет «заметную роль в управлении обществом» также необходимо применять общеэлитарный критерий, обоснованный в работах В.Парето, а именно: «достижение наивысших результатов в своей сфере деятельности». Да и политическая жизнь свидетельствует, что можно играть «заметную роль в управлении обществом» и добиваться поразительно низких, негативных и даже катастрофических результатов в сфере управления обществом. К примеру, заметную роль в управлении (принятие стратегических решений) играл правящий класс царской России начала XX века, но результаты его правления известны. Или советский правящий класс во второй половине ХХ века? Члены Политбюро ЦК КПСС, безусловно, играли заметную роль в управлении обществом. Но каков результат их управленческой деятельности? Распалась и исчезла страна. Каких наивысших результатов добился правящий класс фашистской Германии? Каких результатов добилась бакиевская правящая группировка в Киргизии? А ведь все эти правящие группы принимали стратегические решения, играли заметную роль в управлении обществом. Сторонники функционального (десизионного) подхода относят их к политической элите. Хотя и говорят о такого рода элите как о вырождающейся элите. Но не правильнее ли будет употреблять более точное понятие к таким правящим группировкам?

Ещё раз подчеркнём, правящий класс, правящие группировки любой страны играют заметную роль в управлении обществом. Но если последовательно применять центральную идею теории элит, то всё же следует измерять результаты функиионирования данного правящего класса (группы) и лишь затем отвечать на вопрос о возможности номинации этой правящей группы в качестве политической элиты.

Можно лишь предположить, почему при определении правящей элиты В. Парето отходит от критерия «наивысшие результатов в своей сфере деятельности» и выдвигает иной критерий ««заметная роль в управлении обществом». Видимо состояние науки конца XIX - начала XX века не позволяло сколько-нибудь достоверно измерять эффективность деятельности политической элиты. Однако, спустя столетие, в конце XX - начале XXI века, наука вплотную подходит к решению этой задачи. Как подчёркивают современные исследователи, до середины 1990-х годов измерение качества государственного управления считалось невозможным. Но, к примеру, программа «Показатели эффективности государственного управления в странах мира», которая проводится в рамках Всемирного Банка, показала, что это не так. Эта программа представляет собой новейшее достижение в области разработки периодических показателей качества государственного управления. Для аналитиков различных стран она может стать важнейшим средством оценки ситуации в своих странах в сопоставлении с показателями других стран и тем самым стать основой для сравнения правящих группировок в различных странах. Кроме того, важно видеть, что глобализация ставит правящими группами разных стран много общих задач и проблем и это ещё одна основа для сравнения результатов деятельности правящих сил разных стран.

Программа «Показатели эффективности государственного управления» опровергла избитое утверждение о том, что качество государственного управления не поддается надежному измерению, а извлеченные уроки невозможно применять в деятельности правительств, сообщества организаций, содействующих развитию гражданского общества и средств массовой информации» [11].

Как известно, в рамках исследования Всемирного Банка качество государственного управления осуществляется по шести направлениям:

1. Учет мнения населения и подотчетность государственнblx органов. Это направление оценивает, в какой степени граждане страны имеют возможность выбирать правительство, оценить такие аспекты общества, как свобода слова, свобода объединений, наличие свободных СМИ.

2. Политическая стабильность и отсутствие насилия. Данное направление позволяет оценить существующие представления о степени вероятности дестабилизации и свержения правительства неконституционными методами или с применением насилия, в том числе терроризма. 
3. Эффективность работы правительства. Оценка качества государственных услуг, качества работы государственных служащих, степени независимости государственных служащих от политического давления, качества выработки и реализации политики, надежности приверженности правительства заявленной политике.

4. Качество законодательства. Оценка способности правительства формулировать и реализовывать рациональную политику и правовые акты, которые допускают развитие частного сектора и способствуют его развитию.

5. Верховенство закона. Оценка степени уверенности различных субъектов в установленных обществом нормах, а также соблюдения ими этих норм, в частности, эффективности принудительного исполнения договоров, работы полиции, судов, уровня преступности и распространения насилия.

6. Борьба с коррупцией. Оценка распространенности использования государственной власти в корыстных целях, включая мелкие и крупные формы коррупции, а также степени «учета» государством интересов элиты и частных предпринимателей [11].

Можно дискутировать и критиковать слабости различных измерений качества государств [2, с. 81-82], но очевидно, что именно качество государства, выполнение им своих функций - это то, что отражает эффективность и качество деятельности политической элиты. Российский исследователь М.Афанасьев, на мой взгляд, совершенно верно подчёркивает, что «...именно качество государства является главным вопросом, главным критерием», по которому оценивается правящий класс[10]. Эффективность правящего класса - это результативность, проявляющаяся в функционировании государства, осуществления им задач и функций в политической системе, в обществе, на международной арене.

Задачи для правящего класса современной России в основе своей давно сформулированы Конституцией РФ. Эти задачи очень конкретны, но до сих пор далеки от реализации. По эффективности осуществления этих задач, прежде всего, следует оценивать правящий сегодня в России класс. Среди таких задач и обязанностей для государства и, безусловно, для правящего класса в Конституции РФ сформулированы следующие (укажем лишь немногие): формирование демократического, правового, социального государства, в котором гарантируется государственная «...защита прав и свобод человека и гражданина» (ст.2 Конституции РФ). Но усилиями правящих сегодня в стране сил создана система пренебрежения правами и свободами человека.

Согласно Конституции РФ «единственным источником власти в Российской Федерации является её многонациональный народ», а «захват власти или присвоение властных полномочий преследуются по федеральному закону» (ст.3). Вместе с тем, массовая фальсификация выборов не заметна лишь власть имущим. А ведь фальсификация выборов - это одна из форм антиконституционного присвоения власти.

«В Российской Федерации признаются и защищаются равным образом частная, государственная, муниципальная и иные формы собственности» (ст. 8), но до сих пор в стране процветает рейдерство.

«Граждане РФ имеют право собираться мирно, без оружия, проводить собрания, митинги и демонстрации, шествия и пикетирования» констатирует статья 31, а статья 15 утверждает, что «Конституция РФ имеет высшую юридическую силу, прямое действие и применяется на всей территории Российской Федерации». Но то, что происходит с защитниками статьи 31, знают не только россияне, но и мировая общественность.

«Органы законодательной, исполнительной и судебной власти самостоятельны» (ст. 10), но то, что это не так, знает и власть и народ. О разделении властей высшие лица государства говорят в форме долженствования и высказывают лишь пожелание о том, что «...у нас должно быть реальное разделение властей, каждая из которых должна быть самодостаточной и иметь собственную компетенцию. При этом одна власть не должна погружаться и принимать участие в решениях другой» [9] (курсив мой - Б.В.). Тем самым можно сделать вывод о том, что и сегодня страна далека от реализации важнейших задач конституционного устройства нашей жизни.

То, что мы наблюдаем в современной России - это издевательство над Конституцией.

Понятно, что современный правящий класс в России реализует совсем иные задачи, выполняет совсем иные функции. Политическая группировка современной России добивается наивысших результатов, прежде всего, в сфере удержания власти и через власть - собственности. Уже в 2004 году в Независимой газете от 10.09. появилась достаточно любопытная и насыщенная информацией статье года под названием «Администрация президента берёт командные высоты в экономике. Государственные монополии переходят под персональный контроль представителей Кремля». Вот вывод автора этой статьи: практически все руководство кремлевской администрации к настоящему времени встало у руля крупнейших российских предприятий, контрольный пакет акций которых принадлежит государству. Причем в тех отраслях, которые считаются стратегическими: нефтегазовый комплекс, военно-промышленный комплекс, транспорт, а также телеиндустрия.

С целью защиты сложившейся системы власти и собственности радикально возросло влияние военно-силовых структур в стране. Как отмечал бывший советник президента по экономическим вопросам А. Илларионов в интервью «Эхо Москвы»» в 2007, «...77\% из тысячи важнейших государственных постов в России занимают люди, имеющие отношение к спецслужбам»[4]. Полагаю, что бывший советник президента является компетентным экспертом в вопросе о том, представители каких структур возобладали в институтах власти современной России. Для убедительности можно привести и результаты исследований известного элитолога О. Крыштановской, которая отмечает, что «...на 2007 год, - это последний год президентства Путина, - в администрации президента было 66,6 \% людей из любых силовых структур»[5]. В контексте политического процесса последних лет становятся 


\section{Право и политика 4 (160) • 2013}

понятными мотивы изощренных ходов нынешних обладателей власти в России, направленные на дальнейшую монополизацию и закрепление за собой властных полномочий.

Страх за содеянное становится важнейшим мотивом консервации политического процесса в России. Совершенно верно утверждает О. Крыштановская: «Авторитарный правитель нигде практически не может уйти от власти просто. Потому что в борьбе с врагами (а у авторитарной власти всегда есть враги, так как она подавляет) правитель ставит под удар свою личную безопасность и безопасность своих людей. ...У него реально много врагов. И потеря власти означала бы для него большой риск, возможно - потерю свободы, а может быть, и потерю жизни. Поэтому из-за вопросов личной безопасности ни один авторитарный правитель не покидает власть. В этом слабость авторитарных режимов. Невозможно просто уйти. И даже если ты хочешь этого, твое окружение тебе этого не позволяет, потому что окружение боится, что они не смогут сохранить ни деньги, ни собственность, ни свободу» [6].

Действительно, утрата власти угрожает не только политическому, но и физическому существованию некоторых её высших представителей.

В сфере оценки результатов деятельности политических группировок всегда существовал такой, казалось бы, абстрактный, но сегодня вполне измеряемый процесс, как «общее благо». Вместе с тем, опираясь на измерение общезначимых результатов правления той или иной политической группы, становится возможным измерять и определять её способность использовать государственную власть в качестве инструмента решения общезначимых проблем. Подчеркнём, речь идёт не об измерении некоторых нравственных качеств этого класса, что характерно для аксиологического подхода, речь идёт об измерении эффективности использования политическим классом государственной власти как инструмента решения общезначимых проблем.

Применять к правящему слою современной России понятие «элита» - значит, допускать не только теоретическую погрешность, но и сознательно или бессознательно выполнять апологетическую функцию. Ведь «термин» элита сам по себе содержит идеологически возвышенный, оценочный аспект. Неправильно и даже аморально, - отмечает Г. Ашин, - применять термин “элита” без учёта того, что имеются в виду лучшие, наиболее достойные люди. Инструментальный подход к определению элит, который представлен в данной статье, предполагает выявление в правящих слоях, группировках и т.д., «наиболее достойных» на основе классического критерия «элитарности» - «достижение наивысших результатов в своей сфере деятельности», а именно: в сфере политики, продуктом которой является «общее благо».

\section{Библиография:}

1. Ашин Г. Курс истории элитологии. http://www.gumer.info/ bibliotek_Buks/Polit/Aschin/01.php

2. Барциц И. Н. Показатели эффективности государственного управления (Субъективный взгляд на международные стандарты) // Представительная власть - XXI век: законодательство, комментарии, проблемы. 2008. № 2-3.

3. Гаман-Голутвина О.В. Политические элиты России. Вехи исторической эволюции. - М., 2006.

4. Илларионов A. http://www.echo.msk.ru/news/368017.html

5. Крыштановская O. http://echo.msk.ru/programs/atthistory/657444-echo/

6. Крыштановская O. http://www.polit.ru/lectures/2008/07/31/ rus_elita.html

7. Крыштановская О. Анатомия российской элиты. - М., 2005.

8. Парето В. Компендиум по общей социологии // Антология мировой политической мысли. В 5 т. Т.2.

9. Путин В. Даю вам честное партийное слово // Коммерсант. 30.08.2010.

\section{References (transliteration):}

1. Ashin G. Kurs istorii elitologii. http://www.gumer.info/bibliotek_Buks/Polit/Aschin/01.php

2. Bartsits I. N. Pokazateli effektivnosti gosudarstvennogo upravleniya (Sub'ektivnyy vzglyad na mezhdunarodnye standarty) // Predstavitel'naya vlast' - XXI vek: zakonodatel'stvo, kommentarii, problemy. 2008. № 2-3.

3. Gaman-Golutvina O.V. Politicheskie elity Rossii. Vekhi istoricheskoy evolyutsii. - M., 2006.

4. Illarionov A. http://www.echo.msk.ru/news/368017.html

5. Kryshtanovskaya O. http://echo.msk.ru/programs/atthistory/657444-echo/

6. Kryshtanovskaya O. http://www.polit.ru/lectures/2008/07/31/ rus_elita.html

7. Kryshtanovskaya O. Anatomiya rossiyskoy elity. - M., 2005.

8. Pareto V. Kompendium po obshchey sotsiologii // Antologiya mirovoy politicheskoy mysli. V 5 t. T.2.

9. Putin V. Dayu vam chestnoe partiynoe slovo // Kommersant. 30.08.2010. 